\title{
Physical Factors Determining Women's Football
}

\author{
M. Akbar Husein AllSabah ${ }^{1 *}$, Weda $^{2}$ \\ $\left\{\right.$ akbarhusein@unpkediri.ac.id $\left.{ }^{1}\right\}$ \\ Fakultas Ilmu Kesehatan dan Sains, Universitas Nusantara PGRI Kediri ${ }^{1,2}$
}

\begin{abstract}
The physical factor in women's soccer is very important for the players who play it. Having a good physique for soccer is very important because having a good physique can demonstrate technical skills and tactics in the game of football. The training done by women's soccer is very different from men's soccer. Coaches need to provide the best exercises to be able to develop physically for players. There are several physical biomotors that need to be developed in order to get a good physical. To find out the dominant physical can be known by looking at the forms of training provided by the trainer. The process of training by the coach is a development of techniques, tactics, mental as well as physical for female soccer players. The training models provided by the coach are also supporting factors for female soccer players. Knowing the physical factors determining women's soccer achievements are expected to be able to contribute to the development of other training models that can truly develop the physical female soccer players.
\end{abstract}

Keywords: Women's soccer, Physical, Training

\section{Introduction}

Football is a game of football, football is contested between players who intend to put the ball in to the opponent's goal and defend the goal themselves do not get included. "Football is a team game, each squad consists of eleven players, players using legs, body and head except goalkeepers may use all limbs in the penalty area" [16]. In football there are several divisions: goalkeeper, defender, midfielder, and striker. As with other team sports, football also relies on cooperation or inmpakmpakkan in its team to win games. Today in the game of football, in addition to techniques, tactics and mental physical condition also plays a very important role in the effort to jump into the professional world, because physical condition is considered as a basic factor for a football athlete to be able to compete well. Physical condition training plays a very important role in athlete training programs, especially achievement sports athletes. This is because physical condition training refers to a systematic, planned, and progressive exercise program aimed at improving the functional capabilities of the entire body system to improve athletes' achievements.

Modern football is a tight and difficult competition. Footballers now have to live faster, stronger, and more agile, so that the standard of physical condition of footballers also continues to improve. "Physical condition is the ability to face the physical demands of a sport to perform optimally" [1]. Physical condition training is important to improve the condition of football athletes. The goal of physical training in football is to enable players to face the demands of the game as well as enable efficiency of the use of technical and tactical competencies throughout the game. The physical condition must be noticed by a coach both in regular training and in the face of championships so that a coach can know the physical condition of the player. In addition 
to physical condition training becomes very important to provide weight training, physical conditions can be developed optimally. But the reality is that many coaches ignore the physical condition component of coaching football athletes, resulting in a decrease in the quality of the physical condition of the athletes making it difficult to achieve maximum achievement.

\section{Results and Discussion}

Football is a fairly societal sport and is loved by all walks of life from children to the elderly. Many championships have been held in various world events such as the Champions League, World Cup, European Cup and so on. From these football events are able to hypnotize all the people in the world to watch football games. Many European countries use the game of football as a National sport. Batty [3] says that: Football is a simple game, and the secret to a good game of football is to do simple things as best you can. Another definition of football is the game of kicking a ball contested by players from two different elevens with the intention of putting the ball in the opponent's goal and defending the goal itself not to get the ball [6]. "The game of football is an 11-on-11 game led by a referee and assisted by two line judges, the game takes place on a field that is 100-110 meters long and 64-75 meters wide, with a 12 centimeter field line and equipped with two gawahs that are 2.44 meters high and 7.32 meters wide. The ball used was from the skin. A $2 \times 45$-minute game time consisting of two rounds and a 15-minute break, for a half-game system that only lasts $2 \times 45$ minutes without any additional time, for matches that use the knockout system, if the score is still the same after the match time of $2 \times 45$ minutes is exhausted, there is an additional time of $2 \times 15$ minutes, and if the score is still the same, then a penalty shootout is made. The idea of the game of football itself is to put the ball in the opponent's goal as much as possible and defend our goal from the entry of the opponent's ball" [13].

From some of the above understanding of football can be drawn the conclusion that football is a game between 2 (two) squads consisting of 11 (eleven) players and played with feet, except goalkeepers, may use their hands in the penalty box area. Each team tries to put the ball in to the opponent's goal as much as possible and keep the goal from being entered by the opponent's attack. In football training activities are very important in helping to improve the ability to do sports activities. To enable improved achievement, exercise must be guided by certain theories and principles of exercise. Without doing regular exercise, it is impossible for athletes to achieve the expected achievements. According to Bompa \& Buzzichelli [4] that exercise is usually defined as a systematic process that is carried out repeatedly, progressively, and has the aim of improving physical appearance. According to Scheunemann [15] training in the sport of football is to have four factors or elements that should be considered in fostering or coaching football in order for players to gain good skills. Four aspects of training that need to be carefully observed and trained by athletes, namely physicality, technique, tactics, and soul togetherness. The principles of exercise will support efforts in improving the quality of an exercise. According to Sukadiyanto [17], the principles that can be entirely implemented as guidelines for the purpose of the exercise are achieved in one face-to-face, among others: (1) the principle of readiness, (2) individual principles, (3) the principle of adaptation, (4) the principle of overload, (5) the progressive principle (improvement), (6) the principle of specification (specificity), (7) the principle of variation, (8) the principle of heating and cooling, (9) the principle of long-term exercise, (10) the opposite principle, (11) the principle of not exaggerating, (12) the thematic principle. The principles of exercise are for sports in general, but football training especially for 
young people should pay more attention to the factors that can result in injury, because in young people are very susceptible to injury. This is according to the report Verburgh, Scherder, van Lange, \& Oosterlaan [19], Children who play football may incur injury as a result. The damage can be due directly to physical contact during play or may be attributable to training. Differences between children and adults in physical and physiological characteristics explain why children may be the more vulnerable to injury. The factors that contribute to this greater risk in children include a larger surface area relative to mass, growing cartilage which can be easily stressed, and the fact that children have not yet gained the complex motor skills or experience associated with injury avoidance". There are several exercise factors or variables in the form of exercise size or dosage. According to Ambarukmi [2] the size or dosage of such exercises includes FITTE (Frequency, intensity, time, type, and enjoyment).

The goal of the exercise objective according to Harsono [7] is, "to assist the athlete in improving his skills and achievements to the fullest." To achieve this, there are four aspects that athletes need to be carefully considered and trained in: (a) physical exercise, (b) technical exercises, (c) tactical exercises, and (d) mental exercises. On the physical factors in doing exercises in football players there are several determining physical factors that are trained during training. Physical exercise in football, especially in women's football, has many components, of which the coach makes a schedule-based training program that includes several physical factors. The physical condition components in women's football consist of components such as muscle strength, muscle endurance, general endurance, flexibility, speed, coordination, agility, and balance.

Developing or improving physical conditions in football practice means developing or improving the physical abilities that footballers have. Physical fitness includes two components, namely physical fitness and motor fitness. Physical freshness consists of muscle strength, muscle endurance, respiratory-circulatory endurance, and flexibility. While the components of motion freshness consist of speed, coordination, agility, muscle explosiveness, and balance. Physical condition training means athletes are given exercises of their physical freshness components and the components of their motion freshness. Components of physical condition consist of muscle strength, muscle endurance, circulatory and respiratory endurance, as well as joint flexibility. While that includes motor fitness consists of; speed, coordination, agility, muscle explosiveness, and balance. Thus each athlete should be trained the components of his or her physical condition with an exercise program that is organized in accordance with the principles of exercise. Furthermore Harsono [7] suggested that, "Before being parachuted into the arena an athlete must already be in a good physical condition and fitness level to deal with the intensity of work and all sorts of stress that he will face in the match.

The women's soccer game, having prominent components of physical condition is strength, power, speed of motion, agility, and general endurance (aerobic ability). Because the character of the game of women's football is to make quick and long movements, in order for the movements made in women's football such as kicking, herding, throwing, then women's football players must have good physical condition. Therefore the game of women's football when viewed from the use of its work system physiologically is a combination of work and aerobics. The following are some of the components of physical condition required in women's football.

\subsection{Muscle Strength Limbs}

Strength is the ability of a muscle or group of muscles to cope with weights or prisoners [11]. While according to Harsono [7] states that strength is a very important component to improve overall physical condition. This is because: (1) strength is the driving force of each 
activity, (2) strength plays an important role in protecting athletes/people from possible injuries, and (3) strength can support the ability of more efficient physical conditions, although many sports activities require more agility, flexibility, speed, explosiveness and so on.

But these factors are still combined with strength factors in order to get good results. One of the factors that plays a role in the achievement of kicks is the physical condition of the muscle strength of the limbs. In other words, to achieve a kick there must be an element of physical condition especially the strength of the limb muscles used to lift the thighs and resist at the time of kicking the ball. The muscle strength of a person's limbs plays an important role in increasing the frequency of a person's running steps, since the frequency of steps is the multiplication between the strength of the muscles of the limbs and the speed of the muscles in stepping. This limb muscle strength is used when running dribbling, and kicking the ball, with strong limb muscles then the kick will get stronger.

A female footballer must have strong legs, strong ankles, strong knees and strong limbs in order to carry a heavy weight. In achieving the speed of the ball kick, the muscle strength of the limbs is very influential. Because muscle is a supporting factor in a person's ability to step foot. Thus, a person who has good muscle strength can do and shoulder the heavy work for a long time. People who are physically fresh will have strong muscles and are able to work efficiently. In football this muscle strength is necessary to overcome the burdens that are present at the time of play, and the application is more to the carrying capacity for the physical condition of the power.

\subsection{Speed}

Speed is a fundamental physical component, so speed is the deciding factor in sports such as short-distance running numbers, swimming, martial arts, and gaming sports. Speed is the ability to perform similar movements in a row in the shortest time or the ability to travel a short distance [14]. According to Sukadiyanto [18], speed not only involves the entire speed of the body, but involves the reaction time performed by an athlete against a stimulus. This ability creates a shorter distance to move the body. Speed not only means moving the whole body quickly, but it can also move the limbs in the shortest possible time. In sprint sprints the speed of his run is determined by the successive movements of the legs performed quickly, the speed of kicking the ball is determined by the short limbs in the distance of kicking motion.

\subsection{Agility}

Agility is one of the physical components that is widely used in sports. According to Ismaryati [9], agility is the ability to change the direction and position of the body or its parts quickly and precisely. "characteristics of agility are changes in the direction of running, changes in body position, and changes in the direction of body parts". Sajoto [14] defines agility as the ability to change direction in a particular arena. A person who is able to change direction from position to different position in high speed with good motion coordination means his agility is quite high. While according to Nash, Sproule, \& Horton [12], states that agility is used directly to coordinate multiple movements, make it easier to practice high technique, movement can be efficient and effective, facilitate orientation and anticipation of opponents and competing environments, avoid injuries.

The agility performed by athletes or football athletes when training or competing depends also by the ability to coordinate the body's movement system with response to the situation and conditions faced. Agility is determined by the speed factor of reacting, the ability to control the 
situation and being able to control movement suddenly. Agility is one component of physical condition that is widely used in sports, agility is an element of mobility ability that a football athlete must have, because with high agility athletes can save energy in game time. Agility is also necessary in freeing yourself from the control of the opponent by dribbling, passing the opponent by attacking to create a goal that will lead to victory. An athlete who is less agile in making a move will find it difficult to avoid individual touches that can result in individual mistakes.

\subsection{Durability}

According to Nash et al. [12] endurance is the ability of a person's organism to fight fatigue that arises while carrying out activities for a long time. If a person is able to move a certain group of muscles continuously for a long time, that leads to a good heart, circulation and breathing. The higher a person's level of endurance the higher his physical freshness. In this sport of endurance football is necessary to maintain the condition of the body physically in order to be able to carry out the game for a long time.

According to Sukadiyanto [18], the understanding of endurance reviewed from muscle work is the ability to work muscles or groups within a certain period of time, while the understanding of endurance of the energy system is the ability to work the organs of the body within a certain period of time.

\subsection{Power}

Power is a combination of muscle strength and speed. If two athletes can lift barbels weighing $50 \mathrm{~kg}$, but one can lift faster than the other then he is said to have better power than the one who lifts it slowly. ower is the ability of muscles to exercise maximum strength in a very fast time. Thus because power is a combination of strength and speed then to develop power, female football players must develop their strength and speed. Therefore if a female footballer does not have a good kick or does not have a good throw of the ball then the player is she does not have the perfect power. To increase power in female football athletes can be developed through the addition of strength and speed exercises on the arms or limbs.

\subsection{Balance}

Balance according to Check \& Schutt [5], is the ability to maintain our neuromuscular system in static conditions, or control the neuromuscular system in an efficient position or attitude as we move. While according to Harsono [7], balance is easy for people to control and maintain the position of the body. Furthermore according to Michael [10], balance is "the ability of the individual to control organic equipment neuromuscularly".

In sports activities there are two kinds of balances, namely static balance and dynamic balance. These two forms of balance are often needed in sports. To develop and improve the agility of athletes, one of them must first develop the body balance, especially dynamic balance. A good dynamic balance will be able to prevent a person from falling, if the movement pattern changes unexpectedly. 


\subsection{Coordination}

Coordination is a very complex biomotor capability. Coordination is closely related to the speed, strength, durability, and flexibility of joints, and is a very important component for learning and developing techniques and tactics. Coordination is important in dealing with unfamiliar situations and lingkunagn, such as new pitches, sudden changes in the field of matches, equipment, weather, lights and so on. Coordination can help in quick adjustment efforts with new situations and conditions. Whether or not a person's motion coordination can be reflected in his ability to perform a movement smoothly, precisely, and efficiently. Athletes who have good coordination are not only able to perform a skill perfectly, but also easily and quickly can perform smelly skills, so that the movement becomes efficient.

\section{Conclusion}

Women's football is a growing sport in Indonesia, the development of women's football in Indonesia is characterized by the number of women's soccer clubs and women's soccer competitions. As the organizer and person in charge of women's football has made every effort to manage women's football in order to excel. Women's football in order to achieve so it is necessary to prepare by doing training vigorously. Practice in football in addition to mastering techniques, tactics and mentally also to build the physical ity of the player. The physical factor of the player is very important in the sport of football in achieving achievement, according to Husein [8] saying the physical factor is very important for each player to have so that the player can show a good performance when competing.

\section{References}

[1] AllSabah, Muhammad Akbar Husein., Weda,. Setiawan, Irwan., Nimah, A. S. (2020). Erratum: Profil Kondisi Fisik Pemain Sepakbola Wanita Candra Kirana. JUARA: Jurnal Olahraga, 4(2). https://doi.org/10.33222/juara.v5i1.928

[2] Ambarukmi, D. A. dkk. (2007). Pelatihan Pelatih Fisik Level I. Deputi Bidang Peningkatan Prestasi dan IPTEK Olahraga. KEMENPORA.

[3] Batty, E. C. (2003). Latihan Sepakbola: Metode Baru Serangan. Bandung: Pioner.

[4] Bompa, T. O., \& Buzzichelli, C. A. (2019). Peridization: Theory and Methodology of Training. In Journal of Chemical Information and Modeling.

[5] Check, J., \& Schutt, R. K. (2017). Research Methods in Education. In Research Methods in Education. https://doi.org/10.4135/9781544307725

[6] Conenello, R. M. (2010). Soccer. In Athletic Footwear and Orthoses in Sports Medicine. https://doi.org/10.1007/978-0-387-76416-0_21

[7] Harsono. (2015). Kepelatihan Olahraga. Bandung: PT. Remaja Rosdakarya.

[8] Husein, M Akbar Sabah, A. (2017). Profile Of Physical Ability Of Persik Kediri Player. Proceeding ICSSH, 1(1), 307-311.

[9] Ismaryati. (2008). Tes dan Pengukuran Olahraga. Surakarta: LPP UNS dan UNS Press.

[10] Michael, B. (2013). New Functional Training for Sports. In Journal of Chemical Information and Modeling.

[11] Mylsidayu, A., \& Kurniawan, F. (2015). Ilmu Kepelatihan Dasar. Bandung: Alfabeta. 
[12] Nash, C. S., Sproule, J., \& Horton, P. (2008). Sport Coaches' Perceived Role Frames and Philosophies. International Journal of Sports Science \& Coaching. https://doi.org/10.1260/174795408787186495

[13] PSSI. (2010). Peraturan Sepak bola Moderen. Jakarta: PSSI.

[14] Sajoto, M. (2002). Peningkatan dan Pembinaan Kekuatan kondisi fisik. Semarang: Effhar dan Dahara Prize.

[15] Scheunemann, T. (2012). Kurikulum sepakbola Indonesia Untuk Usia Dini (U15-U12), Usia Muda (U13-U20) \& Senior. Jakarta: PSSI.

[16] Sucipto. (2000). Sepakbola. Jakarta: Dirjen Pendidikan Dasar dan Menengah.

[17] Sukadiyanto. (2005). Pengantar Teori Dan Melatih Fisik. Yogyakarta: FIK Uiversitas Negeri Yogyakarta.

[18] Sukadiyanto. (2011). Tori dan Metodologi Melatih Fisik. In Bandung: Lubuk Agung.

[19] Verburgh, L., Scherder, E. J. A., van Lange, P. A. M., \& Oosterlaan, J. (2016). The key to success in elite athletes? Explicit and implicit motor learning in youth elite and non-elite soccer players. Journal of Sports Sciences. https://doi.org/10.1080/02640414.2015.1137344 